Print ISSN: 2233-4165 / Online ISSN: 2233-5382

doi:http://dx.doi.org/10.13106/ijidb.2018.vol9.no12.55.

\title{
The innovation diffusion and neighbors in the 4th wave through Dubai-city
}

$$
\text { 두바이 도시혁신에 따른 주변국가의 4차산업 혁신확산 }
$$

\author{
Dae-Sung $\mathrm{Seo}($ 서대성)*, Dong-Hwa Kim(김동화)**
}

Received: November 15, 2018. Revised: November 30, 2018. Accepted: December 05, 2018.

\begin{abstract}
Purpose - It suggests that making a policy and strategies for a way of Dubai has a strong priority strategy on science and technology by using much oil dollars to prepare risk when oil dollar's decrease. This has been now investigated how the leading innovator has changed the periphery countries.

Research design, data, and methodology - Analyze policy, status, what other neighbouring Middle East countries also want to benchmark a successful case of a leading Dubai strategy. Higher manpower is needed absolutely to develop S\&T. and etc. Dubai and Arab countries establish university to nurture as well as invite the talented manpower from overseas to recover deficient manpower. Dubai built totally academy city and invited branch of the overseas famous university, and Saudi Arabia built university(KAUST) and invite faculty and support good scholarship for students. Abrab countries especially, This is studied the process of differentiating and integrating the migrant workers of these cities into the globalized cities. This has resulted in large-scale employment for foreign and local companies in these cities and the spread of science and innovation.

Results - Dubai supports venture or SMEs by using a strong priority strategy and attracts foreigner's investor, with which the neighbouring countries have been preparing together for 4th wave. It demonstrates that the gravitational model has been activated from neighboring countries of innovation science to create Dubai's hub. The maturity of long-term urban innovation is related to innovation capability through the national response and review. As a result, the flow of skilled international migration has been localized because of the mutual intersection with the local employment structure, and the development has spread as it spreads to neighboring countries.

Conclusion - For the exploiting of new Distribution market in the neighbouring countries, Middle East countries' a strong priority strategy on S\&T and education system give an influence on economic situation of the 4th wave in the world and world order of leading by USA, Japan, or EU, and etc. This is due to the creation of clusters in the form of SEZs, friendly industrial policies and world-class infrastructure and innovation development. Its neighbours benchmark the cases of distribution of science innovation and centralizes the surrounding people.
\end{abstract}

Keywords: Dubai, Middle East, 4th wave, S\&T, Education, Distribution, Venture, Hub.

JEL Classifications: C12, D12, M11, M31.

1. 서론

4차 산업 혁명은 국가 디지털 트랜스포메이션(Digital transformation) 등의 이름으로 선진국에서 개도국들까지도 변 신을 시도하고 있다. 물론 각 국가마다 환경과 가지 부존자원 은 다르나 과학기술 혁신과 교육을 통해 변신을 하고자 하는 점은 공통사항이다. 이러한 변혁 속에서 선진국과 개도국을 잇 는 주요 역할이 요구된다. 과거 중동은 유럽과 아시아를 잇는

* First author, Professor, Sungkyul University, Division of Paideia, Korea, E-mail: dais3s@gmail.com.

** Director of KEC, TDT University E-mail: worldhucare@gmail.com.
혁신의 교두보 역할을 해왔다.

국가가 과학기술을 발전시키고자 하는 시도는 역사적으로 매우 오래되었다고 볼 수 있으나 그 실효를 가장 크게 나타낸 것은 미국이다. 미국은 2차 대전 후 최대의 패권국가로 부상 하였는데 이것은 과학기술 발전에 의해 군사력이 혁신적으로 앞섰기 때문이라고 결론 짓고 있다(Paarlberg, 2004). 이와 같 은 현상은 미국의 건국 초기부터 문제 해결을 위해 실용기술 을 개발하고 이를 적극 지원할 수 있는 경영능력을 과학기술 에도 도입하여 다른 나라와 차별화한 점이 한 몫 더 했다고 판단된다. 사회의 분위기도 $\mathrm{H} / \mathrm{W}$ 기반의 과학기술이 전반적으로 팽배 해 있었기 때문에 현재와 같은 S/W 기반의 지식 과학기 술이 도입되었다고 보기는 어렵다고 생각한다. 
과학기술은 국가의 발전은 물론 최근 많이 대두되고 있는 경제성장, 일자리 창출, 복지, 군사력, 사회문제 해결, 건강, 수 명 등 다방면에 직접적으로 영향을 주기 때문에 각 국은 심혈 을 기울여 발전시키고자 노력하고 있다.

이러한 현상은 최근 더욱 영향력이 커져 각국은 과학기술을 발전시킬 수 있는 정책 개발, 인재양성, 유치 등을 적극적으로 추진하고 있다. 한국은 1970 년대부터 과학기술 육성 및 인재 유치를 적극적으로 하여 경제 개발에 성공한 나라이다. 그러나 당시 다른 나라들은 고전적인 농업 및 자원개발에 기반을 두 고 경제 성장을 추진하였다. 당시 농업이나 자원에 기반을 두 고 경제 정책을 추진해온 태국이나, 필리핀이 현재와 같이 저 개발국 형태를 벗어나지 않는 것은 과학기술을 등한시한 것이 가장 큰 원인 중의 하나라고 판단된다.

중동의 경우도 1970년부터는 석유라는 가장 큰 경제 재원 을 기반으로 경제성장이나 복지를 추진해 왔으나 2000년대 이 후로는 과학기술의 중요성을 인식하여 막대한 오일달러를 이 용하여 과학기술 우선정책, 인재양성, 오일 달러 이후의 국가 경영 전략을 추진하고 있다(Kim, 2015).

이를 가장 효과적으로 추진하는 나라가 UAE이다. 이미 많 은 보도 자료가 나와 있기 때문에 많은 사람들이 지금은 알고 있지만 초기만 해도 많은 다른 나라 사람들이 성공에 대한 의 문을 가졌다. 두바이의 아카데미 시티(Academy city)는 이렇게 해서 형성된 사막위의 거대한 대학 도시이다(Gremm, 2015).

두바이가 과학기술 중심으로 정책을 펴는 과정에서 다른 중 동국가들도 이를 벤치마킹해 과학기술 육성정책을 펴고 있다 (Michael Bond, etc., 2013). 과학기술이 발전하기 위해서는 고 급인재가 절실히 필요하다. 이를 극복하기 위해 세계 유수의 대학 유치를 적극적으로 하는가 하면 아예 대학을 세워 고급 인재를 육성하고 있다. 사우디아라비아의 KAUST(King Abdullah University of Science and Technology, https://www.kaust.edu.sa/en)는 2009년 9월 23일 설립된 신설 대학이지만 교수진에 대한 파격적인 대우와 많은 장학금으로 전 세계로부터 고급인재를 불러 모으고 있다.

이와 같은 중동 국가들의 과학기술 우선 정책 및 고급인재 양성은 미국, 유럽, 일본 등의 선진국 주도형 세계경제 질서에 많은 영향을 주고 있다. 과학기술 우선정책은 물론 창업도 적 극적으로 지원하는 형태이다(UAE business council, 2017).

이러한 정책과 중소기업, 고급인력에 대한 실질적인 지원 정책 등은 과학기술을 발전시키고, 창업을 유도함은 물론 외국 투자자들이 몰려들게 하는 원동력이 된다. 이러한 환경변화는 경제력을 증가시키고 외부 미국, 아시아, 유럽 등 외부세계에 대한 영향력을 확대시키고 크게는 세계질서를 변화시킬 수 있 다. $\mathrm{OPEC}$ 가 발족하기 전에는 석유가격이 각국의 정책에 의해 결정되었으나 OPEC가 설립되면서 부터는 중동의 석유 정책 에 의해 유가가 결정되었으나 오일쇼크로, 사실상 80 년대 이 후 $\mathrm{OPEC}$ 은 시장에 유가 결정권을 넘겨준 상태로 있다. 그렇 지만, 여전히 세계 경제에 중요한 영향력을 행사해 오고 있다.

물론 이러한 경제적 영향력이 단기간에 형성된 것은 아니 다. 장기간에 걸쳐 $\mathrm{OPEC}$ 협력이 긴밀해지면서 형성된 세계 질서이다. 이와 같이 막대한 오일 달러를 이용해 포스트 오일 시대를 준비하는 중동국가가 늘어나고 인력이 유입되면 과학 기술 분야의 영향력은 더욱 커질 것이다. 또 이들 고급인력들 의 교류가 활발해져서 협력의 필요성이 제기되면 향후 이들 국가들이 OPEC와 같은 협력단체를 형성하지 못하리라는 보 장은 없다. 이는 곧 세계질서 개편에도 영향력을 줄 것으로 생
각한다.

본고에서는 이러한 관점에서 중동지역의 과학기술이 세계경 제 및 세계질서 특히 '한국에 어떠한 영향력을 줄 것인가'에 초점을 맞추어 기술하고자 한다. 현재 원전건설로 협력사례로 보면, UAE 원전 설계는 한국전력기술이 맡고, 원자로 및 증기 발생기 등 기기 제작은 두산중공업, 건설은 현대건설·삼성물산, 핵연료 공급은 한전원자력연료, 운영은 한국수력원자력, 유지 및 보수는 한전KPS가 담당하고 있기 때문이다. 2011년 시작 한 원전 공사는 $\mathrm{UAE}$ 수도 아부다비에서 서쪽으로 $270 \mathrm{~km}$ 위 치한, 바라카 1호기의 경우 공정률이 $96 \%$ 이며, 2018년 안에 완공될 것이다. 나머지 3 기도 2020년 모두 가동을 시작하기 때문이다.

최근에 과학기술 우선 정책을 적극적으로 펴고 있는 나라들 의 정책과 현황을 기술하고 이를 바탕으로 한국에는 어떠한 영향을 줄 것인지 판단하고자 한다. 중동국가를 모두 기술한다 는 것은 그리 큰 의미가 없다. 따라서 최근 활발히 인재를 유 치하고 적극적으로 창업을 지원하는 등 중동 국가들의 현황을 파악하고자 한다. 끝으로 한국은 어떠한 대처 방안을 가지고 접근할 것인지 과학기술 측면에서 대안도 기술해 보고자 한다.

\section{2. 중동국가들의 과학기술 확대}

\section{1. 중동 과학인적유통의 허브}

중동의 과학유통의 위상(HOUSE OF LORDS Select Committee on International Relations 2nd Report of Session 2016-17, The Middle East: Time for New Realism)은 각 유럽 도시와 아시아 사하라이남 아프리카의 물류 허브기점으로 중 동의 지리정치경제학적 위치를 잘 갖고 있다. 지정학적 위치만 큼 중요한 것은 인구와 자원으로 중동국가들의 잠재성을 나타 낸다.

중동 국가들의 통계학적 인구(IMF, 2010)로 조명하면, 아시 아, 유럽, 아프리카에 연결된 교차지점으로 인하여 문명과 교 역의 중개역할을 역사적으로 많이 해왔다. 역사적으로도 문명 이 많이 발달된 시기도 있었으나 석유가 발견되면서부터는 강 대국들의 패권에 더욱 중요한 위치를 차지하게 된다. 이러한 거대한 인구와 오일달러로 인해 세계에 대한 막대한 영향력을 행사해 왔다. MENAP Oil exporters에서 볼 수 있는 바와 같이 중동국가들의 대부분은 오일을 수출한다. 오일을 수출해 얻은 막대한 자금은 군사력, 경제력의 기반이 되고 있고 이는 곧 미 국과 같은 패권 국가들이 쉽게 중동을 포기할 수 없는 원인이 되기도 한다. 중동국가들의 오일 수출 및 재정 현황은 중동국 가들의 오일 수출 및 제정 현황으로 재정에 막대한 역할을 한 다. 이로 인하여, 국가나 개인은 여유가 생기면 문화가 발달하 고 이를 기반으로 과학기술이 발전한다. 또 발전된 과학기술을 이용해 다른 창조적인 패러다임이 창출된다. 또 인재를 중시하 는 사회적 관점이 되기도 한다.

그러나, 2008년 글로벌 위기시기에 두바이는 모라토리엄을 선포했다. 이는 국제적으로 커다란 파장을 일으킨 이유는 산유 국 중 하나이기 때문이었다. 두바이월드의 수요를 예측하지 못 한 투자에 있었다. 또한, 두바이 GDP의 $50 \%$ 가 건설과 부동산 으로 산업구조였기 때문이다. 그 당시 국영기업 두바이월드의 부채는 530 억 달러로 국가부채는 $75 \%$ 에 해당했다. 
결국은 최근에 일고 있는 중동 국가들의 과학기술 우선 정 책이나 세계적 대학을 세워 인재를 양성하고자 파격적인 인재 유치를 추진하고 있다. 이러한 정책들은 중세기 중동이 발전되 었던 문명을 재현하고자 하는 발상의 한 축으로 볼 수 있다 (Hillel Ofek, 2013).

이에 대한 본 연구는 혁신과학의 확산 단계 및 산업 모델 시스템이 중동 주변국가에서 혁신결정의 단계 속도에 미치는 영 향을 검토하여 다음 단계별의 가설과 같이 고려하고 있다.

Hypothesis 1: 단기적으로 혁신지수의 모형은 오일 생산성 및 정보 흐름 성과와 관련이 있다.

Hypothesis 2: 장기적 도시혁신의 성숙도는 국가 대응과 검 토를 통한 혁신 모형과 관련이 있다.

Hypothesis 3: 결과적으로 새로운 유형의 도시 혁신은 국가 의 전략적 의사결정 단계 및 허브 성과 사이 의 균형 관계에서 도출된다.

\section{2. 혁신기반의 대비}

아랍에미리트(Emirate)는 1971년 영국으로부터 독립한 국가 이다. 7 개(아부다비, 두바이, 샤르지, 라스 알 카이마, 아즈만, 움우알쿠와인, 푸자이라)의 에미리트(Emirate)가 연방국가 (Federation)를 결성하여 독립국가 형태로 운영되고 있다. 이 중 두바이는 연방국가 중 하나로 혁신적인 국가 운영으로 세 계에 잘 알려져 있다. 이 본고에서도 두바이를 중심으로 기술 한다.

두바이는 혁신적인 국가 운영으로 세계인들의 관심이 되어 왔다. 인공섬 구축, 금융 허브 구축 등을 거쳐 가학기술 인재 양성을 시작으로 지식 기반 사회를 구축하는데 중점을 두고 있 다. 2014년 예산 중(125억 불) 중 $21 \%$ 해당하는 금액을 교육 에 투자하고 있다. 이들은 곧 두바이 지식촌(Dubai Knowledge Village), 두바이 대학 시티(Dubai International Academic City) 라는 거대한 프로젝트로 실천하고 있다. 1953년도 이전에 세 워진 아랍의 대학들과 1993년도 이전에 세워진 아랍 대학들을 연구역량과 규모, 대학 수를 비교해보면, 매 20년마다 3배 이 상 증가했다. 또 교육자유무역지대를 건설하여 해외 유명 대학 유치하여 현재 10 개국 37 개 외국대학이 UAE에 분교 설립하였 고, ICT를 발전시키기 위해 다양한 ICT관련 자유무역 지대 및 테크노 파크를 건설하였다(Techno Park, Dubai Internet City, Dubai Media City, Dubai Studio City, Dubai Silicon Oasis 등).

Table 1: UAE Innovation Index analysis

\begin{tabular}{|c|c|c|c|c|c|c|c|}
\hline & $\mathbf{2 0 1 1}$ & $\mathbf{2 0 1 2}$ & $\mathbf{2 0 1 3}$ & $\mathbf{2 0 1 4}$ & $\mathbf{2 0 1 5}$ & $\mathbf{2 0 1 6}$ & $\mathbf{2 0 1 7}$ \\
\hline $\begin{array}{c}\text { Innovation } \\
\text { Index }\end{array}$ & 42 & 44.4 & 41.9 & 43.2 & 40.1 & 39.4 & 43.2 \\
\hline $\begin{array}{c}\text { oil } \\
\text { revenue/GDP }\end{array}$ & 26.62 & 26.18 & 24.16 & 21.74 & 12.26 & 14.55 & - \\
\hline $\begin{array}{c}\text { Globalization } \\
\text { index }\end{array}$ & 75.72 & 75.67 & 75.66 & 76.02 & 74.4 & - & - \\
\hline Relative rate & 1.58 & 1.70 & 1.73 & 1.99 & 3.18 & 2.70 & - \\
\hline
\end{tabular}

이는 혁신과 세계화 지수가 상당히 높은 반면에 석유 수익 률은 지속적으로 하락하고 있기 때문이다. 두바이 도시정책의 혁신과 투자개발이 이와 상응하여 나타났다. 이는 Hypothesis
1. 단기적으로 혁신지수의 모형은 오일 생산성 및 정보 흐름 성과와 관련이 있다고 볼 수 있다.

실제 두바이는 혁신과 비전 2021을 제시해 왔다. 혁신은 경 쟁력 있는 경제를 구축하는 혁신적인 Emirates에 중점을 둔 Vision 2021의 '지식의 결합(United in Knowledge)' 기둥의 일 부이다. 이 기둥의 핵심 성과 지표 중 하나는 글로벌 혁신 지 수였다. 아랍 에미리트 연방은 2017년 글로벌 혁신 지수 (Global Innovation Index, GII)에서 모든 아랍 국가를 제치고 세계 35위를 차지하여 지난 2016년 41위의 6개 지역을 세계 에서 가장 혁신적인 국가 중 하나로 자리매김했다.

위의 <Table 1>과 같이 글로벌 혁신 지수(Global Innovative Index)는 국가의 혁신 성과를 측정했고, 이러한 혁신 투입은 기관, 인적 자본 및 연구, 인프라, 시장 등 비즈니스 정교함을 기반으로 검토된다. 혁신 성과는 지식 및 기술 산출물과 창조 적 산출물에 의해 측정되었다. UAE는 아부다비 혁신 지수 (Abu Dhabi Innovation Index)를 포함한 자체 측정 도구를 채 택하여 혁신의 진척상황을 모니터링 했다. 이 지수는 188 개국 경제에서 수행되는 광범위한 사회 경제적 활동 전반에 걸친 기존의 투입 및 산출 지표 데이터를 사용하여 정책 입안자와 의 관련성이 가장 큰 것으로 즉, 새로운 사회 경제적 가치 창 출에 초점을 두었다. 이 새로운 지수는 이전 측정치보다 데이 터에 대한 설득력 있는 해석을 제공하고 경제 내외부에서 더 나은 비교우위를 생성함으로써 실질적으로 중요한 혁신을 반 영하도록 설계되었다.

두바이가 혁신과 기술의 허브를 지향하고 있다. 첫째, 미래 의 박물관이다. 이 목표를 달성하기 위해 2015년 3월부터 미 래 지향적인 혁신과 디자인 그리고 주요 관광지를 위한 독특 한 인큐베이터가 될 미래의 박물관을 시작해왔다. The Museum of Future는 신생 기업 및 세계적 기술의 대기업의 최신 발명품 및 프로토 타입을 시연하고 테스트할 수 있는 플 랫폼을 제공했다. 대학, 기업 및 연구 파트너와 혁신 시설 및 디자인 스튜디오를 개방했다. 이는 고급 전문 워크숍이나 공개 회담 및 행사가 진행되었다.

둘째, 세계 최초의 3D 인쇄 건물이다. 2016년 5월 두바이 에서 세계 최초의 $3 \mathrm{D}$ 인쇄 건물로 미래의 사무실로 시연했다.

셋째, 두바이에서 혁신을 촉진하는 자유 지역이다. 예를 들 어, Tecom Group은 Innovation Hub라는 180만 평방피트 규모 의 새로운 거대한 타운을 설립이다. 혁신 허브는 아이디어 창 출, 네트워킹, 지식 공유 및 역동적인 산업 이벤트를 촉진시킨 다. 혁신 허브(Innovation Hub)에서 Tecom은 기술, 뉴미디어, 스마트 교육 및 과학 분야의 새로운 아이디어를 탐구할 혁신 적인 커뮤니티 공동체를 창출하려 한다.

다음과 같은 혁신의 주요 성과가 있었다. UAE는 혁신 주도 경제를 목표로 하는 유일한 아랍 국가이므로 지식 기반 경제 를 위한 성장 동력의 일부로 혁신 시스템을 개발하고 향상시 키고 있다. 이 UAE는 최근 유럽의 선도적인 비즈니스 스쿨 인 INSEAD에 의해 중동에서 가장 혁신적인 국가로 선정되었 다. 강력한 기술 기반과 고품질 교육 시스템을 들었다.

본 연구에서 제시하는 UAE의 주요 혁신 성과사례를 세분화 할 수 있다.

첫째, 학교 내 컴퓨터 및 스마트 기기의 교육 및 도입이며, 둘째, 고등교육기관 설립 확대이다. 셋째, 연구, 창의력 및 혁 신을 촉진하기 위한 다수의 복합단지 및 연구기관 및 기술연 구소 설립: 아부다비의 마스다르 시티(Abu Dhabi's Masdar City), 두바이 과학 공원(Dubai Science Park), 모하메드 빈 라 
시드 솔라파크(Mohammed bin Rashid Solar Park), 샤 르자의 아랍 과학 기술 연구소(Arab Institution for Science and Technology in Sharjah), 라스 알 카이 마 기술과 혁신 센터 (Technology and Innovation Center in Ras Al Khaimah), 응 용 연구 및 연수 센터(CERT -The Centre of Excellence for Applied Research \&Training )

넷째, 대중에게 정보 통신 기술을 전파하고 제공, 다섯째, 정부 및 비정부 부문에서 $\mathrm{e}$ 러닝 문화 장려, 여섯째, 다수의 연방 기관으로부터 아랍 에미리트 연방 최고위원회 구성, 일곱 째, Be'tha 장학금 프로그램 내에서 대통령 국무부와 전기 통 신 규제 당국 간의 협조적 협정을 실행하여 정보통신 분야에 종사하는 전문 분야의 최고의 국제 대학에서 공부할 수 있는 기회를 제공했다.

\section{3. 두바이의 혁신 분석과 확산}

두바이는 국가차원에서 스마트 국가를 건설하겠다는 전략을 세우고 추진 중이다. 이 전략을 통해 기술혁신을 실천하고 경 제성장을 이루겠다는 목표이다. 추진하고자 하는 전략 중에는 자율주행 택시의 구현, 국가의 서비스의 질 향상을 위한 소프 트웨어 도입, 초등교과 자료의 디지털화, 스마트 홈 및 병원의 모바일 헬스케어, 인공지능 및 데이터를 이용한 정책 결정, IoT를 이용한 스마트시티 건설은 물론 최근에 우려를 하고 있 는 블록체인 기술도 채택하여 혁신을 이루겠다는 전략이다.

이와 같은 정책은 디지털 정부를 구현하여 인쇄에 소모되는 자원을 절약하고, 블록체인 관력 기술을 활용해 부동산, 금융, 의료, 교통, 에너지절감, 가버넌스 등 다양한 산업을 발전시키 고, 이 기술은 국제 무역이나 여행객의 여권 승인 관련 문제에 도 적용하여 혁신을 이루겠다는 국가적 차원의 전략을 가지고 있다. 이 정책이 인정받아 유엔은 1990년과 2015년 사이에 가 장 빠르게 발전하는 10 대 도시 중 하나로 두바이를 선정한 바 있다. 혁신적인 국가는 또 다른 혁신을 낳는다.

세계에서 빠른 도시의 성장이 기대되고 통계청에 따르면 2016년 약 240만 명 인구에서 2030년에는 약 520만 명으로 증가할 것으로 전망하고 있다. 각종 기적적인 기록에 의해 관 광객이 많아지고 국제 학술대회도 많이 개최된다. 2020년에는 약 2,000만 명 이상으로 증가할 것으로 예상하고 있다. 급격한 도시 팽창은 많은 전력 수요를 요구한다. 전략 수요를 충족시 키기 위해 태양광 발전을 시도하고 있다. 이를 위해 이미 2014년도 IBM과 MOU를 체결해 스마트에너지 과제를 협업 진행하고 있다. 주요 기술 내용은 건물에 스마트미터를 설치하 여 전략 사용량을 감시하고 건물에는 태양광 에너지 시스템을 설치하도록 정부가 지원하는 내용 등이다.

스마트 생활의 가장 대표적인 것 중 하나는 쇼핑몰 주차 시 스템으로 빈공간은 빨간색 안내 등으로 알려 이용객의 불편을 최소화하는 것이다. 간단한 기술인 것으로 보이나 두바이의 관 광객과 쇼핑몰 크기가 워낙 커서 주차 시는 빈공간과 쇼핑 후 자기 위치를 알기 어렵다. 이러한 문제를 해결한 것이다. 쇼핑 몰의 경우 8,000대까지 주차할 수 있는데 자기 차를 찾는 것 이 쉽지 않으리라는 것은 이해를 할 수 있을 것이다.

\section{1. 혁신사례와 4차 산업사회의 변화}

두바이는 이미 세계적인 인공물들로 유명하다. 사막위에 세
운 세계 최고층 건물, 세계 최대 쇼핑몰, 인공섬, 세계 최고급 호텔, 세계 최대 인공화원, 세계 최대를 지향하는 공항 등 이 루 헤아릴 수 없이 많다. 이러한 최고 및 최고급의 시설을 보 기 위해 많은 관광객이 몰린다. 관광객은 막대한 관광수입을 걷어 들인다.

2016년 두바이국제공항 이용객 수는 8,300만 명으로 세계 3 위를 기록하고 있다. 이들에 의해 형성된 관광수입은 310 억 달러(약 33 조 원)로 추산되고 있다. 같은 해 런던의 100 억 달 러와 많은 차이가 난다. 혁신적 사례는 혁신적인 결과를 선순 환 적으로 낳는다는 것을 입증하고 있다. 두바이는 혁신적 기 술을 지속적으로 추진하기 위해 세계 최초의 인공지능 담당 장관을 두고 있다. 한국인의 생각으로는 기이하다 할 정도이지 만 인공 섬을 건설한 것과 같은 발상이다.

2017년 9월에 4차 산업혁명을 국가정책에 도입하기 위한 전략에 따라 신설된 것이다. 두바이는 이미 $3 \mathrm{D}$ 프린팅으로 건 설한 사무용 건물도 사용하고 있는데 2030년까지 많은 건물 (25\% 정도)을 이러한 방식으로 짓는다는 계획도 추진 중이다. 또한 솔라 공원은 두바이 시민과 주민들에게 청정에너지를 제 공하기 위해 태양광 및 집적 태양광 발전 기술을 사용했다. 혁 신 센터, 연구 및 개발센터, 시험시설 및 태양열로 강화된 담 수화 플랜트를 통합한 것을 보여준다.

로봇을 이용한 경찰 시스템, 무인 공항택시, 드론 택시 시도 등 혁신적인 기술을 도시 정책에 추지하고 있다. <Table 1>은 혁신적 정책에 의해 또 혁신적 결과를 생산하는 사례를 제시 하고 있다. 두바이는 혁신적 사례뿐 아니라 과학기술 및 교육 도 혁신적으로 추진하고 있다. 그 사례가 아카데미시티이다. 여기에는 이미 세계적인 대학들이 분교를 운영 중인데 23개 외국 대학들이 들어와 있다. 이들은 두바이 대학시티에 있는 외국대학들로 혁신을 창출해 나가고 있다.(Abu Dhabi University, American University in the Emirates(AUE), Amity University Dubai, BITS Pilani University, Dubai, Curtin University, ESMOD Dubai, Heriot-Watt University Dubai Campus, Hult International Business School, Imam Malik College, Institute of Management Technology(IMT), Dubai, Islamic Azad University(IAU), Manchester Business School, Manipal University, Dubai, MENA College of Management, Michigan State University Dubai, Middlesex University Dubai, Murdoch University Dubai, S\&P Jain School of Global Management, SAE Institute Dubai, Shaheed Zulfikar Ali Bhutto Institute of Science and Technology, The British University in Dubai (BUiD), UAE University, Universite Saint Joseph Law School, University of Birmingham Dubai, University of Bradford, University of Exeter, University of Wollongong in Dubai).

이렇듯 두바이의 전 분야에서 개발 경제학의 빅푸시 (big-push)이론을 혁신적인 상업으로 적용한 사례로 볼 수 있 다. 이는 과거 국가주의 형태에서 가능한 것이나, 혁신을 허브 에 집중화해서 급성장하려는 전략이다.

\section{2. 미래 4차 과학유통 전략과 연구모형}

두바이 전략들은 혁신실천에 대한 상대평가가 필요했다. 자 유민주주의적 기준으로 볼 때, 두바이는 여전히 시대를 역행하 는 국가다. 민주적 대의 제도도 없고, 언론의 자유는 빈약하며, 동성애는 불법이다. 그러나 다른 아랍 국가와 비교해 볼 때 두 
바이는 대단히 개방적이며 현대적이다. 내각 인원의 $30 \%$ 가 여 성이다. 참고로 사우디아라비아는 $0 \%$, 요르단은 $6 \%$ 에 불과하 다. 또한 공무원의 $66 \%$ 가 여성이다.

다음 연구모형을 통해 다음과 같은 두바이 전략과 주변국의 혁신화 확산으로 전개되게 했음을 제시한다.

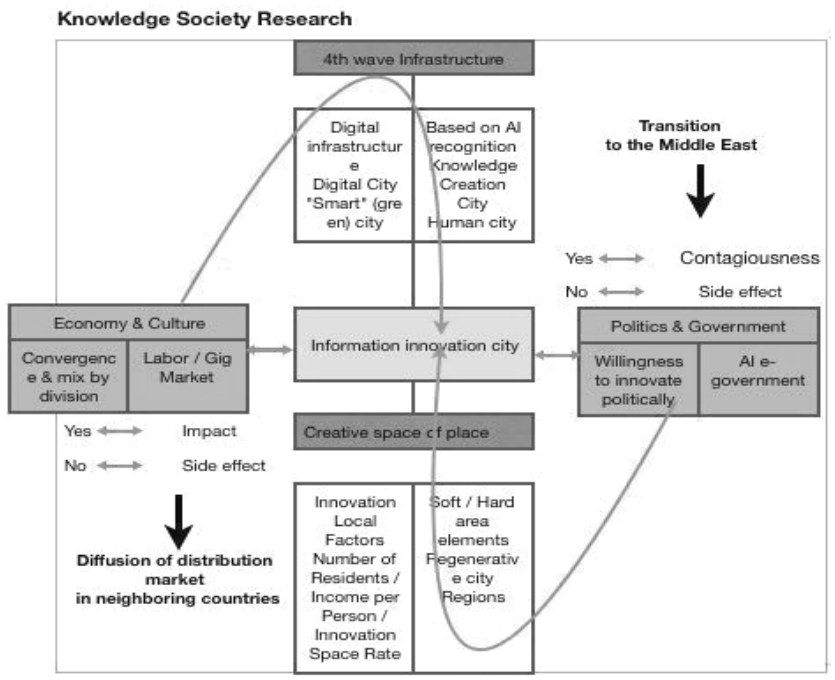

Figure 1: The research model based on the case of Dubai's innovative virtuous cycle

두바이의 장기전략 목표는 미래 성장이 가능한 분위기를 만 드는 전략이다. 두바이는 초기에 행운보다는 선도적인 연구기 술로 이뤄냈다. 본국에도 제한적이지만 석유오일이 매장되어 있고, 이웃하는 아부다비에는 매장량 높은 유전지대가 있다. 그러나 제한된 자원인 석유를 가지고 세계적인 중심지로 연구 혁신시스템으로 재부상 했고 이를 바탕으로 <Figure 1>의 연 구 모델처럼 세계화를 촉진시켰다. 두바이 정부는 미래전략 계 획의 일환으로, 전 세계의 혁신기술을 지닌 스타트업 기업들을 지원하고, 이들의 두바이의 인재유치 입국을 이끄는 1 억 달러 규모이상의 펀드를 조성하고 있다. 두바이는 다양성과 관용성 이 기술 혁신과 사회변화를 가져오고 미래의 질서를 새롭게 하는 것을 희망한다. 그리고 기술 혁신연구와 정책들은 경제적 번영을 불러올 것이고, 또한 두바이 정부가 말하는 행복 스마 트 도시를 건설할 것으로 본다. 그러나 에미레이트인들 이외의 난민과 외국인들에게 시민권을 주지 않아도 행복 도시를 만들 수 있는가? 이는 현재로서는 답에 이의를 제기한다.

본 논고의 Hypothesis 3.은 Ewers and Dicce(2016)가 제시 한 숙련된 국제 노동자들이 두바이와 아부다비의 급속하게 세 계화되는 도시에 차별적으로 집중 유입되고 통합되어 이들 도 시의 이주노동자들을 양분하는 과정을 연구했다. 이는 이들 도 시의 외국 및 지역 기업에 대한 대규모 고용 조사의 결과와 이들 기업들과 함께 실시한 주요 정보 제공 인터뷰를 통해 분 석이 연구되었다. 가장 중요한 것은 글로벌 도시 노동시장에서 확고한 고용 관행이 주정부 규제 체계 및 현지 고용 구조와 교차하므로 숙련된 국제 이주 흐름이 현지화되었다. 이는 논문 의 연구 결과에서 제시하는 혁신과학의 주변국으로부터 중력 모형이 작용되어 두바이의 허브화를 조성했음을 방증한다.

\section{4. 과학혁신의 유통과 재편}

두바이 도시는 2006년부터 UAE 의회에 여성정치인의 참여 와 더불어서, 다음 지표들이 중동 사막 위에 연구 혁신을 토대 로 건설된 두바이를 통해 중동지역 국가들에게 모범이 되고 있음을 방증해 준다.

Table 2: Percentage of Women in the UAE Congress and World Investment Rate

\begin{tabular}{|c|c|c|c|c|c|c|c|c|c|c|c|c|}
\hline & $\mathbf{2 0 0 6}$ & $\mathbf{2 0 0 7}$ & $\mathbf{2 0 0 8}$ & $\mathbf{2 0 0 9}$ & $\mathbf{2 0 1 0}$ & $\mathbf{2 0 1 1}$ & $\mathbf{2 0 1 2}$ & $\mathbf{2 0 1 3}$ & $\mathbf{2 0 1 4}$ & $\mathbf{2 0 1 5}$ & $\mathbf{2 0 1 6}$ & $\mathbf{2 0 1 7}$ \\
\hline $\begin{array}{c}\text { Percentage } \\
\text { of women } \\
\text { in } \\
\text { Congress }\end{array}$ & 5 & 22.5 & 22.5 & 22.5 & 22.5 & 17.5 & 17.5 & 17.5 & 17.5 & 22.5 & 22.5 & 22.5 \\
\hline $\begin{array}{c}\text { World } \\
\text { Investment }\end{array}$ & 0.6 & 0.46 & 0.21 & 0.08 & 0.47 & 0.31 & 0.42 & 0.45 & 0.6 & 0.4 & - & - \\
\hline $\begin{array}{c}\text { Relative } \\
\text { ratio }\end{array}$ & - & -0.14 & -0.25 & -0.13 & 0.39 & -0.16 & 0.11 & 0.03 & 0.15 & -0.2 & - & - \\
\hline
\end{tabular}

두바이는 주변 다른 나라가 하지 못하는 할 수 없는 정책들 을 혁신적으로 추진, 실천하고 있다. 왕정국가의 장점을 살려 정책에 반영하여 단기간에 실질적으로 정책을 실천한다는데 세계에 대한 영향력을 학대하고 있다. 두바이시가 인공섬을 시 도 한다고 할 때만 해도 세계인들이 반신반의했다. 그러나 그 것을 실천하여 현재는 가장 앞선, 혁신적인 도시를 건설하여 이를 기반으로 세계적으로 관광산업의 판도를 바꾸고 있다. 전 통적으로 관광산업하면 아름다운 자연경관에 풍부한 유럽식 문화만을 생각해 왔다. 사막이 관광자원이 되리라고는 생각하 지 않았다.

예를 들어, 첫째, 세계적인 인공 조형들로 세운 스마트한 도 시이다. 두바이몰, 부르즈 칼리파, 팜 주메이라, 두바이 미러클 가든, 부르즈 알 아랍, 스키 두바이 등 다양한 혁신도시를 이 루었다.

둘째, 이색적인 혁신기술이 두바이에 막대한 관광수입으로 주변 중동 국가의 개방을 가져왔다. 두바이 정부는 2020년엔 관광객 수가 2천 만 명 이상으로 전망하여 전략화하고 있다. 2016년 두바이 국제공항의 이용객 수는 세계 3 위(8,300여만 명), 방문객 수는 4 위(1,500만 명)다. 관광객들이 한 해 두바이 에서 지출한 돈은 약 310 억 달러(약 33조 원) 이상이다. 국제 공항협회와 마스타카드 인덱스로 비교해 보면, 두바이 세계 1 위이며, 2 위인 런던보다 100 억 달러나 더 차이가 난다. 아랍에 미리트항공은 최대 800 여 명을 수용할 수 있는 A380의 100여 대를 보유하고 있고 앞으로도 2 배까지 증대할 계획이다.

Table 3: Annalysis of Competitiveness(C),Social globalization(SG), Business freedom(BF), Labor freedom(LF) index

\begin{tabular}{|c|c|c|c|c|c|c|c|c|c|c|c|c|c|}
\hline & 2006 & 2007 & 2008 & 2009 & 2010 & 2011 & 2012 & 2013 & 2014 & 2015 & 2016 & 2017 & 2018 \\
\hline BF & 49 & 49 & 48 & 57 & 67 & 67 & 68 & 74 & 74 & 75 & 80 & 81 & 80 \\
\hline SG & 80.59 & 80.04 & 80.58 & 80.14 & 79.5 & 78.82 & 78.73 & 78.91 & 81.69 & 74.15 & - & - & - \\
\hline LF & 74 & 74 & 74 & 76 & 79 & 72 & 79 & 78 & 83 & 84 & 81 & 81 & 81 \\
\hline C & 4.5 & 4.5 & 4.68 & 4.92 & 4.89 & 4.89 & 5.07 & 5.11 & 5.33 & 5.24 & 5.26 & 5.3 & - \\
\hline Inclease & 0 & 0 & 0 & 0.11 & 0.12 & -0.08 & 0.08 & 0.05 & 0.08 & -0.06 & 0 & 0 & 0 \\
\hline
\end{tabular}

셋째, 두바이에 혁신기술과 연구로 계획된 수만큼이나 상용 화되었기 때문에 이를 다른 국가들도 재편하고 있다. 2017년 
9월 4차 산업 혁명 국가전략에 의거해서, 세계 최초 $\mathrm{Al}$ (인공지 능)담당 장관을 신설하여 두바이를 혁신과 신흥 기술의 글로 벌 허브를 구축하고 있다. 두바이 미래전략 수립의 핵심 역할 을 하는 두바이 미래재단 사무실로써, 세계 최초의 $3 \mathrm{D}$ 프린팅 오피스 건물이 세워졌다. 단층 오스피텔(250m)을 건축하는데 18 명의 인력으로 소요된 기간은 단 17 일로 2 배 이상 단축된 다. 두바이 정부는 2030 년까지 두바이 건물의 $25 \%$ 를 $3 D$ 프린 팅 방식으로 건설하고 있다.

넷째, 4차 산업혁명과 더불어 가상화폐인 암호화 화폐의 연 구기술인 블록체인 도입과 상용화에도 가속화하고 있다. 세계 최초의 블록체인 도시 구축을 선포하여 비자 신청, 면허 갱신, 건강 기록 및 부동산 거래 등에 블록체인 기술을 적용하여, 2020년부터는 블록체인 네트워크로 연간 15억 달러의 행정비 용을 절감하려 한다. 2017년 블록체인 혁신은 세계 처음으로 정부 차원의 중앙은행이 발행하는 디지털 암호화폐 엠캐시 (emCash) 도입도 발표했다. 블록체인에 기반을 두어 발급되는 '엠캐시'는 정부신용조사기관 엠크레딧이 보증하는 디지털지갑 '엠페이' 사용자들에게 거래의 안전성과 신속성을 높여주고 거 래 비용을 절감한다. 이는 두바이 시민들은 개인의 소득세에 대한 세금과 소비세를 납부하지 않아도 되며 물가 상승률도 높지 않아서 사업의 시작도, 자산 증식에도 좋은 나라이다. 이 는 두바이에서는 큰 빚을 지는 시민들도 없으며 부채나 빚이 있어도 허용하지 않기에 신용카드를 남용하다 적발되면 범죄 자로 기소되기 때문에 암호화 화폐의 상용화가 가능하다. 가상 화폐의 통화정책은 불가능한 사회에서 새로운 사회질서를 창 출이 나올 수 있으나 여전히 여성 인권이나 사회 문화적의 변 화는 더디 움직이고 있는 것이 현실이다. 다섯째, 새로운 산업 의 연구와 상용화 정책들이 두바이의 중동 안팎으로 확대 재 생산하여 형성해 나가고 있기 때문이다.

두바이의 스마트도시와 혁신전략은 공급이 수요를 창출하는 방식으로, 현실에 없는 미래라는 상품을 공급해 중동의 새로운 비전이 수요를 충족시키고 중동지역의 사회질서를 변화시키고 있다고 봐야 할까? 과거 특히 8세기부터 13세기까지 스페인 과, 유럽전역에 혁신을 가져다 준 중동 과학기술의 역사가 재 현될 수 있다.

Hypothesis 2.에서 제시한 결과는 두바이가 혁신적인 기업 가의 역량 강화해 왔다는 것이다. 그 일환으로 GITEX 글로벌 스타트업 운동(GITEX Global Startup Movement)에서 60개국 400 개 이상의 창업 회사와 1,000 개 이상의 기업가가 두바이에 모여 판매 및 연구한다. 아랍 에미리트(UAE)가 85개의 신생 기업으로 구성되는 동안, 신생 기업의 $79 \%$ 가 나머지 국가들로 부터 혁신을 가져 오게 했다. SoftBank Group International, Accell Partners, Golden Gate Ventures, Middle East Venture Partners 등을 포함하여 실리콘 밸리, 유럽, 아시아 및 중동의 200 여 명의 투자자 및 영향력 있는 기술 투자자들이 두바이에 서 연구와 재발견한 가장 유망한 벤처 기업 중 일부를 지역 인재에 대한 특별한 시각을 가지고 평가하고 잠재적으로 자금 을 지원했다. 이는 투자자의 저명한 자금 조달 벤처 기업인 페 이스 북, Dropbox, Spotify 등 글로벌 대기업을 포함되었다.

Hypothesis 3.처럼, 새로운 유형의 도시 혁신은 국가의 전략 적 의사결정에 의해 다음과 같이 나타났다. 주관 기관을 통해 신생 기업들이 전통적인 투자자 및 잠재적 기업과 직접 만나 는 삶의 터전을 바꿀 수 있는 기회를 창출하고 있으며, 자금 지원이나 자문 지침을 통해 합작 투자를 통해 창업에 도움을 준다. 이러한 젊은 창의적인 아랍인들 사이에 그들의 상상력으
로 세상을 바꾸려는 비전이 도출하고 있다.

다른 국가의 동료 신생 기업들과도 더 가까워지며, 그 중 일부는 성공적인 모범사례가 되고 있다. 상호 작용과 공감을 통해 구축된 이 가치 있는 공유 경험은 두바이의 성장에 새로 운 혁신을 불어 넣고 있다. 여러 기관은 기업가 정신에서 이러 한 삶의 변화 기회를 창출할 수 있는 원동력이 될 수 있는 특 권을 부여하고 있다.

$\mathrm{UAE}$ 의 기업가 지원은 중동과 북아프리카에서 최고이며, 세 계에서 19번째이다. 미국의 경제정책 연구소(Pacific Research Institute)에 따르면 신생 기업이 GDP를 각각 120 만 달러 이상 증가시킬 수 있다고 본다. 예를 들어, AstroLabs 두바이는 MENA 지역에서 Google과 제휴한 유일한 Tech Hub이며 AstroLabs의 공동 창업자인 Muhammed Meki는 'Strut-Up' Pitch 경진대회를 심사하고 장려한다. Muhammed는 GITEX 글 로벌 스타트 업 운동(GITEX Global Startup Movement)에서 멘토십 세션을 통해 성공적인 기업가로서의 경험을 공유하고 있다.

1980년대 중반 이후 두바이는 경제 특구의 형태로 클러스 터를 조성하여 친화적인 산업정책과 세계적 수준의 인프라를 제공했다. 이 클러스터는 외국인 투자를 유치하여 두바이의 개 발을 지원했으며, 경제 발전과 다각화의 근간을 이루었다. Al-Saleh(2018)는 실증적 증거를 바탕으로 클러스터 기반 경제 개발을 위한 연구 모델을 분명히 함으로써, 두바이 도시혁신의 경험이 반영했다. 그는 심층적인 인터뷰, 문헌 검토 및 미디어 및 정책 계획 문서의 정밀 조사를 통해 수집된 데이터는 궁극 적으로 두바이의 특정 모델의 주요 특징을 파악하기 위한 기 초 이론을 사용하여 분석되었다. 여기서 주도 개발의 경우 개 발 유산이 궁극적으로 경제 회복력이 향상되는 것을 방지함으 로써 경제 위기의 시대에 UAE를 보호했다. 본 논고에서 제안 된 모델의 연구 결과도 혁신 클러스터 기반 경제 개발을 통해 주변국에 과학혁신개발의 유통에 기여했다고 본다.

\section{5. 결 론}

본고의 시사점은 오일에너지의 패권에 의해 세계를 지배하 는 시대를 벗어났음을 보여 준다. 이는 지적 산업이 경제와 사 회를 이끌어가는 시대에는 혁신적인 아이디어를 얼마나 정책 에 빨리 그리고 많이 접목하느냐로 판가름 난다는 것이다. 다 른 북아프리카나 산유국들이 오일달러를 이용해 개인 재산 축 적의 사례와는 달리, 두바이는 미래를 두고 이를 구현한다는 지도자의 혁신적인 점이 세계적 혁신지형을 변화시킨 것이다, 또한 민주국가들은 대부분 선거에 의해 지도자가 한시적으로 결정된다. 정책에 일관성이 없어지고 아무리 좋은 정책도 전임 자가 추진했던 것들은 없던 일로 해버리는 일이 다반사이다. 그러나 두바이는 왕권을 중심으로 지속적으로 정책을 일관성 으로 여성의 참여까지 다양하게 빅푸시(big push)전략 개발로 추진하여, 세계적인 영향력은 더욱 확대된다. 이는 경제 특구 의 형태로 클러스터를 조성하여 친화적인 산업정책과 세계적 수준의 인프라와 혁신개발을 제공했기 때문이다.

두바이는 사막에 거대한 혁신적인 도시를 건설하여 지금은 세계의 관광산업, 도시의 기본 개념, 항공 산업, 미래 도시, 4 차 혁명 시대의 도시와 삶 등을 실용화하고 하고 있다. 이를 위해 혁신적인 대학촌을 건설하고 세계적인 대학을 유치 인재 
를 집중시키고 양성하고 있다. 이들 모든 정책이나 혁신적인 실천 사항들은 중동은 물론 아시아, 유럽, 더 나아가 세계적으 로 영향력을 확대하여 세계의 판도를 바꾸어 나가고 있다.

본 논고는 제시한 그림 모형을 근거로 데이터를 분석한 결 과, 주변 아랍 국가들이 두바이의 과학 혁신의 유통사례를 벤 치마킹하고 주변 국민들을 집중화시키는 역할을 했음을 방증 하였다.

\section{Reference}

Al-Saleh, Y. (2018). Crystallising the Dubai model of clusterbased development. Place Branding \& Public Diplomacy, 14(4), 305-317.

Bashar, S. (2016). El-Khasawneh A Science and Technology Road Map for Developing Countries. International Journal of Humanities and Social Science, 61).

Cherrier, H., \& Belk, R. (2015). Setting the conditions for going global: Dubai's transformations and the Emirati women. Journal of Marketing Management, 31(3), 317-335.

Chu, D. C. (2018). Employment motivation and job-related satisfaction: a comparison of police women's perceptions in Dubai and Taipei. Policing \& Society, 28(8), 915-929.

Deloitte (2017). National Transformation in the Middle East, $A$ Digital Journey. Retrieved from https://www2.deloitte.com/ content/dam/Deloitte/xe/Documents/technology-media-telec ommunications/dtme_tmt_national-transformation-in-the-mi ddleeast/National\%20Transformation\%20in\%20the\%20Mid dle\%20East\%20-\%20A\%20Digital\%20Journey.pdf.

Dow, K. (2017). Cosmopolitan conceptions: IVF sojourns in global Dubai Problems of conception: Issues of law, biotechnology, individuals and kinship. Journal of the Royal Anthropological Institute, 23(3), 623-625.

DSP (2018). Dubai science park community. Rretrieved from http://www.dsp.ae/community/business-partners/

Ewers, M. C., \& Dicce, R. (2016). Expatriate labour markets in rapidly globalising cities: Reproducing the migrant division of labour in Abu Dhabi and Dubai. Journal of Ethnic \& Migration Studies, 42(15), 2448-2467.

Gremm, J. (2015). Kuwait is the Past, Dubai is the Present, Doha is the Future: Informational Cities on the Arabian Gulf. International, 6(2),1-14.

Kim, J. M. (2013). UAE 's post - oil era strategy and our direction. GCC National Institute of Dankook University.

Ofek H. (2013). Why the Arabic World Turned Away from
Science. Washington, DC: New Atlantis pubulished.

Paarlberg, R. L. (2004). Knowledge as power. International Security, 29(1), 122-151.

Pryde, A. (2017). HOW MARKETING BUILT DUBAI. Cambridge Marketing Review, 1(13), 39-43.

Reisz, T. (2018). Landscapes of Production: Filming Dubai and the Trucial States. Journal of Urban History, 44(2), 298-317.

Sab, R. (2014). Economic Impact of Selected Conflicts in the Middle East: What Can We Learn from the Past? New York, NY: IMF working paper press.

Sarabdeen, J., Rodrigues, G., \& Balasubramanian, S. (2014). E-Government users' privacy and security concerns and availability of laws in Dubai. International Review of Law, Computers \& Technology, 28(3), 261-276.

Seo, D.S. (2018). Strategy of Market SpreadCommercialization in EVs Industry: Visegrad and Nordic Countries. The International Journal of Industrial Distribution \& Business, 9(3), 57-68.

Seo, D.S. (2017). The investment point on cooperative innovation in EVs for the spoke-smart cities: focused on Nordic countries and Korea. The Journals of Economics, Marketing \& Management, 5(3), 1-11.

Seo, D.S. (2016). The Role of Innovative Energy Public Firms' Channels according to Shale Gas for E-Convergence Economy. The Journal of Distribution Science, 14(5), 17-26.

Seo, D.S. (2016). The Commerce Strategy towards Pan-European Innovation and Consumption: Spokes Partnership for FDI of Korea. Journal of Internet Banking and Commerce, 21(S2), 1-7.

UNESCO (2011). UNESCO's Global Observatory on Science, Technology and Innovation Policy Instruments GO, Division of Science Policy and Capacity Building, Natural Sciences Sector. Retrieved from http://www.unesco.org/new/ fileadmin/MULTIMEDIA/HQ/SC/pdf/GO-SPIN_Concept.pdf.

U.S.-U.A.E. Business council (2017). The U.A.E.'S Startup ecosystem and opportunity for us investors. Retrieved from http://usuaebusiness.org/wp-content/uploads/2017/03/lnves t-UAE_EE_digital.pdf.

The economist (2014). UAE Economic Vision: Women in science, technology and engineering. London, England: the economist intelligence unit press.

The Dubai Government (2018). Key sectors in science and technology. Retrieved June 18, 2018 from http://www.dubai.ae/en/Pages/default.aspx. 